\title{
Perception of Extension Personnel on Suitability and Benefits of Using Social Media in Communicating Agricultural Information in Enugu State, Nigeria
} https://dx.doi.org/10.4314/jae.v23i3.15

\author{
Iwuchukwu, Juliana Chinasa \\ Department of Agricultural Extension, \\ University of Nigeria, Nsukka, Enugu State, Nigeria. \\ Email: juliana.iwuchukwu@unn.edu.ng \\ Phone:+2348063276459
}

\section{Eke, Okechukwu George}

Department of Agricultural Extension, University of Nigeria, Nsukka, Enugu State, Nigeria.

Email: okechukwueke89@gmail.com

Phone: +2348064771404

\section{Nwobodo, Cynthia Ebere}

Department of Agricultural Extension, University of Nigeria, Nsukka, Enugu State, Nigeria.

Email: cynthia.nwobodo@unn.edu.ng

Phone: +2348039462574

\section{Abstract}

The study ascertained suitability and benefits of using social media in communicating agricultural information. Ninety-seven extension workers proportionately selected from six agricultural zones in Enugu state, Nigeria constituted sample for the study. Questionnaire was used for collection of data while percentage and mean scores were used to present the data. Findings reveal that the majority (81.4\%) of the respondents possessed facilities used in accessing social media, while Facebook (82.4\%) and Whatsapp (74.2\%) were social media resources used by the respondents. The majority (70.1\%) of the respondents indicated that Facebook is a social medium suitable for communicating the best soil for different agricultural practices, while $69.1 \%$ indicated that it is suitable for creation of awareness and participation in agricultural program/project. Whatsapp is suitable for communicating market situation/agricultural commodity price (56.7\%) and best soil for different agricultural practices (53.6\%). Respondents also indicated reduction of cost of communicating information in agriculture $\left(\begin{array}{ll}\bar{x} & =1.81\end{array}\right)$, increased access to useful agricultural information $(\bar{x}=1.79)$ and covering lapses of high farmer-extension ratio $(\bar{x}=1.77)$ as major benefits of using social media in agriculture. The study concluded that Facebook was social medium suitable for communicating most of agricultural information. Thus, extension personnel and other stakeholders in agriculture should use more of Facebook in communication of agricultural information to enhance effectiveness of extension work and agriculture generally.

Key-words: Social media, agricultural information, suitability, benefit 
Creative Commons User License: CC BY-NC-ND

Abstracted by: EBSCOhost, Electronic Journals Service (EJS),

Google Scholar, Journal Seek, Scientific Commons,

Food and Agricultural Organization (FAO), CABI and Scopus
Journal of Agricultural Extension

Vol. 23 (3) July, 2019

ISSN(e): 24086851; ISSN(Print); 1119944X

http://journal.aesonnigeria.org

http://www.ajol.info/index.php/jae

Email: editorinchief@aesonnigeria.org

\section{Introduction}

Social media refer to a website or internet service that allows users to interact with each other and create content instantaneously (Sophia, Margarita, Theodore and Dimosthenis, 2013). They are wide range of internet-based and mobile services that allow users participate in online exchanges, contribute user-created content or join online communities (Michael, 2012). The evolution of social media provided a visible solution to the challenge of information gap that hinders improvement of standard of living of people and achievement of development (Ministry of Agriculture (MOA), 2013). This is premised on the fact that social media enable blogging, tagging, discussion, networking, and so on (Sokoya, Onifade, and Alabi, 2012) and help to transfer information to large audiences at the same time and at a cheaper rate.

Social media have long been used in agriculture for facilitating communication among stakeholders, especially extension personnel (Sophie, 2013). According to Italie (2015) social media is the most recent form of digital communication and on a global scale accessing news through it by using mobile devices is gaining popularity. Within a few years, it has completely changed communication globally (Suchiradipta and Saravanan, 2016) and has become extremely popular because it allows people to connect in the online world to form a group, a forum and a community where ideas and information can be exchanged without any geographical barrier (Chui, et.al, 2012). They have impacted global development making people more informed and aware. A study conducted by Balkrishna and Deshmukh, (2017) revealed some benefits of social media in agriculture such as prompt response to questions relating to the field, saves time and cost of communication, provision of right information and at the right time like weather report, disease control, etc. Unfortunately, farmers, extension agents and other stake holders in agriculture may not be familiar with these benefits of social media.

Collence (2013) bemoans that the greatest challenge in the use of social media for agriculture is that of accessibility especially on the part of poorer peasant farmers. Kipkurgat, Onyiego and Chemwaina, (2016) note that among the most common challenges faced by farmers in the use of social media in executing farming activities include: poor network access, power outages, and costly charges when accessing the internet. Poverty, old age, illiteracy and most importantly choice of suitable social media tool for specific information are also challenges in the use of social media.

Research on suitability of different social media tools for communicating specific agricultural information is important because if information is to be used for driving agricultural growth and development, it should be communicated in a way, manner and through a medium that promote its delivery, reception and usage. Unfortunately, extension personnel and other stakeholders in agriculture may not have been aware, sensitized and hence may not take cognizance of this fact (suitability) in using social media for communication of information in agriculture. This lapse limits the effectiveness of the information as well as the benefits of using social media in agriculture. 
Creative Commons User License: CC BY-NC-ND

Abstracted by: EBSCOhost, Electronic Journals Service (EJS),

Google Scholar, Journal Seek, Scientific Commons,

Food and Agricultural Organization (FAO), CABI and Scopus
Journal of Agricultural Extension

Vol. 23 (3) July, 2019

ISSN(e): 24086851; ISSN(Print); 1119944X

http://journal.aesonnigeria.org

http://www.ajol.info/index.php/jae

Email: editorinchief@aesonnigeria.

There is therefore the need to capture perception of extension personnel on suitability and benefits of using social media in communicating agricultural information in Enugu State, Nigeria. Specifically, the study ascertained possession and use of social media tools and resources among extension personnel in the state as well as their perceptions on the benefit and suitability of different social media tools for communicating specific agricultural information.

\section{Methodology}

The study was carried out in Enugu State, Nigeria (latitude: $9^{\circ} 04^{\prime} 39.90^{\prime \prime} \mathrm{N}$ and longitude: $8^{\circ} 40^{\prime} 38.84 "$ E). All agricultural extension personnel of Enugu State Agricultural Development Programme (ENADEP) constituted the population for the study. This involves zonal manager (ZM), zonal extension officer (ZEO), subject matter specialists (SMS), block extension supervisors (BES), block extension agents (BEA), and extension agents $(E A)$ in the zones. The total number of extension personnel in the six agricultural zones is 114. Proportionate sampling technique was used to select about $85 \%$ of the extension personnel in the state drawn from each of the zones. This gave a total sample size of ninety seven (97) respondents for the study.

Data for the study were collected through the use of questionnaire. Specifically, data were collected on types of facilities they use to subscribe to social media as well as social media resources they use. To identify specific social media that are suitable in communicating specific agricultural information, different agricultural information and social media such as Facebook, Twitter, Instagram, Whatsapp, Youtube were presented and respondents were asked to indicate those ones that are suitable for disseminating specific agricultural information. Information that were listed include: fertilizer application, erosion control, planting methods, etc. To ascertain perceived benefits of using social media in communicating agricultural information, a three point Likert-type scale of to a great extent (GE), to a little extent (LE) and to no extent (NE) with nominal values "two, one and zero" assigned to them respectively was used. The mean was 1 such that variables with mean scores greater than or equal to 1 were regarded as major benefits while those with mean scores less than 1 were regarded as minor benefits of using social media in communicating agricultural information. Some of the benefits listed were reduction of drudgery in extension work, availability of relevant information, easy connection of extension agents and farmers, etc. Data generated were presented in percentages and mean scores.

\section{Results and Discussion}

\section{Possession and Types of Facilities Used in Subscribing to Social Media}

Results in Table 1 show that the majority (81.4\%) of the respondents possessed facilities used in accessing social media. Also, the majority (72.2\%) of the respondents used smart phone in accessing social media while $23.7 \%$ used laptop to access social media. The respondents are likely to possess and use smart phones to assess social media because of availability of numerous cheap smart phones that can access internet and used for communication faster than desktop, laptop and other gadgets. Also, these phones are portable and can be carried along which may help users like extension workers to 
communicate easily and give prompt response to issues on agriculture especially those that need urgent attention. According to John (2013), smart phones are communication gadgets that provide great functionality and usage to people as they offer better opportunity to communicate with people, learn new things, get exposed on a global scale, develop and improve business and career.

\section{Social Media Used by Extension Personnel}

Table 1 reveals that Facebook $(82.4 \%)$ and Whatsapp $(74.2 \%)$ were social media that the majority of the respondents used for communication. Majority of the respondents may have used Facebook because it is a popular social medium that is easy to use with features that permit blogging, tagging, discussion and networking. This finding is in consistent with Kehinde and Ayobami (2015) who found that Facebook was the most commonly used social media among extension workers. Furthermore, the greater number of respondents that used Whatsapp could be as a result of its popularity and cheap network subscription. According to Kamani, Ghodasara, Soni and Parsaniya (2016), over 27 billion messages are sent by over 300 million users everyday on Whatsapp. In addition to text messaging, Whatsapp users can also make audio and video calls, send each other images, videos, audio media messages, etc with zero cost (Devesh, Mahesh and Sushil, 2017) 
Table 1: Possession of facilities and use of social media by extension personnel

\begin{tabular}{ll}
\hline Facilities & Percentage $(\mathbf{n}=\mathbf{9 7})$ \\
\hline $\begin{array}{l}\text { Possession of facilities used in accessing social } \\
\text { media }\end{array}$ & \\
Yes & 81.5 \\
${ }^{*}$ Facilities used in subscribing to social media & 72.2 \\
Smartphone & 23.7 \\
Laptop & 9.3 \\
Ipad & 3.1 \\
Desktop & \\
${ }^{*}$ Social media resources used by respondents & 82.4 \\
Facebook & 74.2 \\
Whatsapp & 24.7 \\
Twitter & 19.6 \\
Instagram & 4.1 \\
Youtube & \\
&
\end{tabular}

\section{*Multiple responses Source: Field survey, 2018}

Suitability of Different Social Media for Communicating Agricultural Information

Entries in Table 2 show perceptions of respondents on suitability of different social media for communicating specific agricultural information. Thus, the majority $(70.1 \%)$ of the respondents indicated that Facebook is suitable for communicating the best soil for different agricultural practices, $69.1 \%$ indicated that it is suitable for creation of awareness and participation in agricultural program/project while $67.0 \%$ indicated that it is suitable for communicating information on market situation/agricultural commodity price. The suitability of Facebook for these aforementioned information may be derived from the fact that Facebook is the most popular social media in the world (Sophie, 2013), the most likely social media for pages and profiles (Balkrishna and Deshmukh, 2017) and can be easily integrated in delivering content by extension workers in different formats for selflearning of target groups (Saravanan and Suchiradipta, 2017).

Also $62.9 \%$ of the respondents indicated organic farming operation, $61.9 \%$ each indicated pest and disease control, preservation of agricultural produce and sources of improved varieties of crops and animals, while $60.8 \%$ indicated crop production activities as agricultural information that can be communicated through Facebook. Facebook allows people to connect in the online world to form a group, a forum and a community where ideas and information can be exchanged without any geographical barrier (Chui, et al 2012). Agricultural pictures can also be uploaded and shared on Facebook among stakeholders especially extension personnel which facilitate dissemination of agricultural information like those mentioned above to and among target groups.

Other agricultural information that can be communicated through Facebook as indicated by the respondents were: effects of deforestation on agriculture $(59.8 \%)$, how to obtain loan from agricultural banks $(59.8 \%)$, pre-planting operation $(58.8 \%)$, processing of 
Creative Commons User License: CC BY-NC-ND

Abstracted by: EBSCOhost, Electronic Journals Service (EJS),

Google Scholar, Journal Seek, Scientific Commons,

Food and Agricultural Organization (FAO), CABI and Scopus
Journal of Agricultural Extension

Vol. 23 (3) July, 2019

ISSN(e): 24086851; ISSN(Print); 1119944X

http://journal.aesonnigeria.org

http://www.ajol.info/index.php/jae

Email: editorinchief@aesonnigeria.org

agricultural produce (58.8\%), asking and responding to agricultural questions $(56.7 \%)$, animal husbandry (56.7\%), climate change issues and agriculture (55.7\%), fertilizer issues $(53.6 \%)$, effect of flooding on agriculture (53.6\%), importance of cooperatives $(53.6 \%)$ and issues on erosion (51.5\%). According to Lathiya, Rathod, and Choudhary (2015), Facebook allows users to create a profile, add friends, send messages and join common interest groups. These attributes and more of Facebook may have made it appealing to extension personnel in communicating those specific agricultural information highlighted above.

Similarly, the majority $(56.7 \%)$ of the respondents indicated that Whatsapp is suitable for communicating market situation/agricultural commodity price, best soil for different agricultural practices $(53.6 \%)$ and creation of awareness and participation in agricultural program/project $(51.5 \%)$. The majority of these respondents may have indicated Whatsapp because of its" user-friendly application and cheap data subscription (Trisha, 2012 and Saravanan and Suchiradipta, 2017). WhatsApp has the largest community of users with over 600 million users, making it the most popular application for instant messaging (IM), and has found mainstream acceptance and popularity now world over (Aliyu and Safiul, 2017). According to Kamani, Ghodasara, Soni and Parsaniya (2016), using Whatsapp application does not require learning about any new technology. It offers an easy and instantaneous way to communicate with other users. Moreover, the voice messaging feature allows people to communicate without having the knowledge of English and this will allow dissemination of information to illiterate groups like rural farmers in local dialects//vernacular. Majority of the respondents did not perceive Instagram, Twitter and Youtube to be suitable for communicating agricultural information probably because most of them did not use them (Table 1 ) hence are ignorant of their potentials even in agriculture. 
Table 2: Suitability of different social media for communicating specific agricultural information

Agricultural Information

Communicating information on best soil for different agricultural practices

Awareness and participation in agricultural

program/project

Market situation/agricultural commodity price

Organic farming operation

Pest and disease control

Preservation of agricultural produce

Sources of improved varieties of crops and animals

Crop production

Effects of deforestation on agriculture

How to obtain loan from agric bank

Pre-planting operation

Processing of agricultural produce

Answering of agricultural questions and answers

Animal husbandry

Climate change issues and agriculture

Fertilizer issues

Effect of flooding on agriculture

Importance of cooperatives

Issues on erosion

Weather forecasting

Issues on drainage

Issues on irrigation

Source: Field survey, 2018

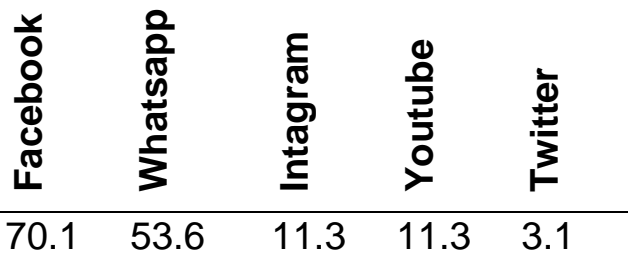

$\begin{array}{lllll}69.1 & 51.5 & 1.0 & 11.3 & 21.7\end{array}$

$\begin{array}{lllll}67.0 & 56.7 & 31.3 & 14.4 & 2.1\end{array}$

$\begin{array}{lllll}62.9 & 44.3 & 8.2 & 6.2 & 3.1\end{array}$

$\begin{array}{lllll}61.9 & 42.3 & 8.2 & 7.2 & 1.0\end{array}$

$\begin{array}{lllll}61.9 & 39.2 & 19.4 & 19.4 & 4.1\end{array}$

$\begin{array}{lllll}61.9 & 44.3 & 3.1 & 3.1 & 2.1\end{array}$

$\begin{array}{lllll}60.8 & 45.4 & 15.6 & 6.2 & 4.1\end{array}$

$\begin{array}{lllll}59.8 & 37.1 & 6.2 & 11.3 & 4.1\end{array}$

$\begin{array}{lllll}59.8 & 41.2 & 8.2 & 9.3 & 2.1\end{array}$

$\begin{array}{lllll}58.8 & 43.3 & 6.2 & 6.2 & 3.1\end{array}$

$\begin{array}{lllll}58.8 & 30.9 & 3.1 & 16.5 & 3.1\end{array}$

$\begin{array}{lllll}56.7 & 34.0 & 3.1 & 7.2 & 18.6\end{array}$

$\begin{array}{lllll}56.7 & 37.1 & 9.3 & 5.2 & 3.1\end{array}$

$\begin{array}{lllll}55.7 & 42.3 & 6.2 & 6.2 & 2.1\end{array}$

$\begin{array}{lllll}53.6 & 33.0 & 17.3 & 3.1 & 3.1\end{array}$

$\begin{array}{lllll}53.6 & 36.1 & 27.5 & 10.3 & 2.1\end{array}$

$53.6 \quad 35.1 \quad 2.1 \quad 5.2 \quad 2.1$

$\begin{array}{lllll}51.5 & 33.0 & 5.2 & 5.2 & 3.1\end{array}$

$\begin{array}{lllll}49.5 & 29.9 & 2.1 & 4.1 & 7.3\end{array}$

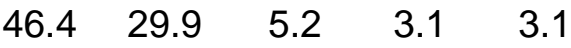

$\begin{array}{lllll}45.4 & 25.8 & 4.1 & 4.1 & 4.1\end{array}$

\section{Perceived Benefits of Social Media in Agriculture}

The major benefits of social media in agriculture as perceived by the respondents were: reduction of cost of communicating information in agriculture $(\bar{x}=1.81)$, increased access to useful agricultural information $(\bar{x}=1.79)$, cover lapses of high farmer-extension ratio in Nigeria $(\bar{x}=1.77)$ and reduction of drudgery in extension work and agriculture in general $(\bar{x}=1.76)$. Truly, use of social media in agriculture helps the extension personnel to communicate information to majority of their target groups at a reduced cost and tine. Internal Development Unit (IDU) (2006) in Casey et al (2016) in a study conducted on cyber Extension found that the web could be effectively used to facilitate extension work, such as appropriate forum for educational outreach and cost-effective means to reach extension agents, educators and opinion leaders who will transfer knowledge gained to their clientele. Social media help extension personnel to stay at their comfort zone and access different forms of information which help them to simplify some ambiguities in agriculture (Saravanan and Suchiradipta, 2016). 
Creative Commons User License: CC BY-NC-ND

Abstracted by: EBSCOhost, Electronic Journals Service (EJS),

Google Scholar, Journal Seek, Scientific Commons,

Food and Agricultural Organization (FAO), CABI and Scopus
Journal of Agricultural Extension

Vol. 23 (3) July, 2019

ISSN(e): 24086851; ISSN(Print); 1119944X

http://journal.aesonnigeria.org

http://www.ajol.info/index.php/jae

Email: editorinchief@aesonnigeria.org

Other benefits of social media in agriculture include : quick marketing of agricultural products through advertisement $(\bar{x}=1.74)$, easy communication of agricultural information $(\bar{x}=1.72)$, prevention of damages by providing solutions to problems associated with agriculture timely $(\bar{x}=1.70$ and helping extension personnel to get feedback on information easily $(\bar{x}=1.70)$. Marketing of agricultural produce is made easy through social media. This could be as a result of countless features of social media applications which permit extension personnel and their client to broadcast, advertise and market their produce with ease. Slvoljub, (2014) also observes that social media is used for accessing market information (prices), weather forecast, advice of agricultural experts

Also, encouraging interactive program between farmers, extension personnel and researchers $(\bar{x}=1.64)$, creation of awareness of vacancy in agricultural firm $(\bar{x}=1.58)$ and securing of agricultural jobs $(\bar{x}=1.41)$ were also perceived by the respondents as benefits of using social media in agriculture (Table 3 ). In support of the finding, Newbury et. al. 2014 assert that availability of some social media like Linkedin, Facebook, Twitter, etc, which are often used in broadcasting employment vacancies may have facilitated the advertisement of job vacancies as well as securing jobs by extension personnel. According to them, creating awareness among extension professionals and building their capacities to share more information through social media equipped them with the ability to secure more opportunities in their careers. Kamani, Ghodasara, Soni and Parsaniya (2016) also indicated that social media can be used in keeping ourselves informed about latest happenings around the world; current updates in the agricultural sector, latest government policies, schemes and subsidies, latest job available, weather forecast, market value of agricultural produce, latest farm machines and technologies related to agriculture.

\section{Table 3: Perceived benefits of social media in agriculture}

\begin{tabular}{|c|c|c|}
\hline Perceived benefits & Mean & Std. Deviation \\
\hline Reduced cost of communicating information in agriculture & 1.81 & 0.417 \\
\hline Increase access to useful agricultural information & 1.79 & 0.432 \\
\hline Covers lapses of high farmer-extension ratio in Nigeria & 1.77 & 0.445 \\
\hline Reduces drudgery in extension work and agriculture in general & 1.76 & 0.516 \\
\hline Quick marketing of agricultural products through advertising & 1.74 & 0.440 \\
\hline Easy communication of agricultural information & 1.72 & 0.473 \\
\hline Helps extension personnel to get feedback on information at ease & 1.70 & 0.482 \\
\hline $\begin{array}{l}\text { Helps in preventing damages by providing solutions to problems associated with agriculture } \\
\text { timely }\end{array}$ & 1.70 & 0.524 \\
\hline $\begin{array}{l}\text { Social media encourages interactive program between farmers, extension personnel and } \\
\text { researchers }\end{array}$ & 1.64 & 0.483 \\
\hline Creation of awareness of vacancy in agricultural firm & 1.58 & 0.537 \\
\hline Securing of agricultural jobs & 1.41 & 0.658 \\
\hline $\begin{array}{l}\text { Helps to build robust relationship among extension workers globally and improve their } \\
\text { capacities of sharing agricultural information }\end{array}$ & 0.72 & 0.579 \\
\hline It can be used in conducting workshop for extension personnel & 0.66 & 0.540 \\
\hline $\begin{array}{l}\text { Promotes easy distribution of logistics to farmers through advertising (ie sharing of videos, } \\
\text { pictures, etc) }\end{array}$ & 0.65 & 0.630 \\
\hline
\end{tabular}

Source: Field survey, 2018 
Creative Commons User License: CC BY-NC-ND

Abstracted by: EBSCOhost, Electronic Journals Service (EJS),

Google Scholar, Journal Seek, Scientific Commons,

Food and Agricultural Organization (FAO), CABI and Scopus
Journal of Agricultural Extension

Vol. 23 (3) July, 2019

ISSN(e): 24086851; ISSN(Print); 1119944X

http://journal.aesonnigeria.org

http://www.ajol.info/index.php/jae

Email: editorinchief@aesonnigeria.org

\section{Conclusion and Recommendation}

Smartphone was the common social media facility respondents used while Facebook was social medium suitable for communicating most of agricultural information such as best soil for different agricultural practices and creation of awareness and participation in agricultural program/project. Also, reduction of cost of communicating information in agriculture and increased access to useful agricultural information were some of the benefits of using social media in agriculture. Thus, extension personnel and other stakeholders in agriculture like farmers and researchers should use more of Facebook in communicating agricultural information with emphasis on those specific information that they are suitable for communicating. This will enhance effectiveness of communication, extension work and agriculture generally.

\section{References}

Aliyu, A. B. and Safiul, I. A, (2017). An overview of social media use in agricultural extension service delivery. Journal of Agricultural Informatics. Vol. 8( 3), 50-61.

Balkrishna, B. B. and Deshmukh, A. A, (2017). A study on role of social media in agriculture marketing and its scope. Global Journal of Management and Business Research: E Marketing. Vol 17 (1), 33-36.

Chui, M., Manyika, J., Dobbs, R., Roxburgh, C., Sarrazin, H., Sands, G. and Westergrens, M., (2012). The social economy: Unlocking value and productivity through social technologies. Retrieved on 17/09/2017 http://www.mckinsey.com/insights/high tech telecoms internet/the social economy

from

.Collence, T.C, (2013). Knotting and networking agricultural information services through web 2.0 to create an informed farming community: a case of Zimbabwe. World Library and Information Congress: $18^{\text {th }}$ IFLA General Conference and Assembly. Available from http://conference.ifla.org/ifla 78 .

Devesh, T., Mahesh, C. and Sushil, S, (2017). Whatsapp for farmers: Enhancing the scope and coverage of traditional agricultural extension. International Journal of Science, Environment and Technology, Vol. 6(4), $2190-2201$.

Internal Development Unit (IDU), (2006) in Casey, M.J, Meikl, P.U, Akerr, G.A. and Stevens, D.R, (2016). Social media - a disruptive opportunity for science and extension in agriculture? Hill Country - Grassland Research and Practice Series 16. ISSN 0110-8581 (Print) ISSN 24634751 (Online).

Italie, H., (2015). Report: Social media drives news consumption. Retrieved on 27/03/2017 from http://www.csmonitor.com/Technology/2015/0430/ consumption. Published on May 30, 2015. 
Creative Commons User License: CC BY-NC-ND

Abstracted by: EBSCOhost, Electronic Journals Service (EJS),

Google Scholar, Journal Seek, Scientific Commons,

Food and Agricultural Organization (FAO), CABI and Scopus
Journal of Agricultural Extension

Vol. 23 (3) July, 2019

ISSN(e): 24086851; ISSN(Print); 1119944X

http://journal.aesonnigeria.org

http://www.ajol.info/index.php/jae

Email: editorinchief@aesonnigeria.org

John, J. (2013). Positive impacts of smart phones on social media. TRFCC media Retrieved on 21/06/2019 from https://www.trffcmedia.com/topics/positive-impacts-of-smartphones-onsocial-society/.

Kamani, K.C., Ghodasara, Y.R., Soni, N.V and Parsaniya, P.S, (2016). Empowering Indian agriculture with Whatsapp : A positives step towards digital India. International Journal of Agriculture Sciences. Volume 8(13), 1210-1212.

Kehinde, A.T. and Ayobami, A.L., (2015). Training needs assessment on the use of social media among extension agents in Oyo State, Nigeria. Journal of Agricultural Informatics. Vol. 6, (1), 100-111.

Kipkurgat, T, Onyiego, M and Chemwaina, S, (2016). Impact of social media on agricultural extension in kenya: a case of kesses district. International Journal of Agricultural Extension and Rural Development Studies. vol.3 (1), 30-36.

Lathiya, A, Rathod, A and Choudhary, K. (2015). Role of social media in agriculture. International Journal of. Commerce and Business Management. vol. 8(2): 268-273.

Michael, N and Jeffrey, D. J. (2014). The Role of Importance Perceptions in Participant Sport. Journal of Physical Education and Sports Management. Vol.1 (2), 29-52.

Ministry of Agriculture (MOA), (2013). State of Indian Agriculture 2012-13. Published by the Ministry of Agriculture, Department of Agriculture and Co-operation, Directorate of Economics and Statistics, New Delhi.

Newbury, E., Humphreys, L., and Fuess, L., (2014) Over the hurdles: Barriers to social media use in extension offices, Journal of Extension, Article number 5FEA1, 52(5).

Saravanan, R and Suchiradipta, B (2017). Social media for agricultural extension. National Institute of Agricultural Extension Management (MANAGE). Bulletin No. 1, March, 2017.

Sokoya, A. A, Onifade, F. N and Alabi, A. O, (2012). Establishing connections and networking: The role of social media in agricultural research in Nigeria. World Liberary and Information Congress. $78^{\text {th }}$ IFLA General Conference and Assembly.

Sophie, S. (2013).Harnessing Social Media in Agriculture. A report for the New Zealand nuffield farming scholarship Trust. www.nuffield.org.nz/uploads/media/S _Final_Report.pdf (Accessed on 20.5.2015).

Suchiradipta, B., and Saravanan, R., (2016). Social media: Shaping the future of agricultural extension and advisory services, GFRAS interest group on ICT4RAS discussion paper, GFRAS: Lindau, Switzerland.

Slavoljub, M. (2014). The role and potential of information technology in agricultural improvement. Agris (61) 2, 471-485. 